\title{
HUBUNGAN PANJANG BADAN LAHIR DENGAN KEJADIAN STUNTING PADA ANAK BALITA USIA 0-59 BULAN DI KABUPATEN JOMBANG
}

\author{
Vivin Eka Rahmawati* \\ *Universitas Pesantren Tinggi darul 'Ulum. Jl. Rejoso Peterongan Jombang 61481 \\ vivineka74@gmail.com
}

\begin{abstract}
ABSTRAK
Gangguan pertumbuhan pada anak akibat dari kurangnya asupan gizi dalam waktu yang lama dapat mempengaruhi terjadinya stunting (anak dengan tinggi badan lebih rendah daripada tinggi badan anak seusianya). Di Indonesia pada tahun 2018, tiga diantara 10 anak balita mengalami stunting dan satu diantara jumlah anak balita mengalami wasting dari jumlah tersebut dan dua diantaranya mengalami wasting. Tujuan dari penelitian ini adalah untuk mengetahui faktor yang mempengaruhi stunting pada anak balita usia 0-59 bulan di Kabupaten Jombang. Penelitian ini adalah penelitian deskriptif analitik dengan teknik pengambilan sampling dengan simple random sampling. Variabel bebas dalam penelitian ini adalah panjang badan lahir, sedangkan variabel terikat yaitu stunting. Penelitian ini menggunakan instrumen berupa kuesioner dengan menggunakan uji chi-square. Hasil penelitian menunjukkan bahwa anak balita (0-59 bulan) yang mempunyai panjang badan lahir $(\geq 50 \mathrm{~cm})$ sebanyak 71 balita $(78,9 \%)$ tidak mengalami stunting sedangkan anak balita dengan panjang badan lahir $(<50 \mathrm{~cm})$ sebanyak 39 balita $(46,4 \%)$ yang mengalami stunting, dari hasil analisis yaitu didapatkan hubungan antara panjang badan lahir dengan kejadian stunting pada anak balita usia 0-59 bulan dengan nilai $p=0,001<0,005$. Dapat disimpulkan bahwa anak dengan panjang badan lahir $\geq 50 \mathrm{~cm}$ menurunkan angka kejadian stunting pada usia $<2$ tahun.
\end{abstract}

Kata Kunci : Panjang badan lahir, Stunting

\begin{abstract}
Impaired growth in children due to lack of nutritional intake for a long time can affect the occurrence of stunting (children whose height is lower than the height of their age). In Indonesia in 2018, three out of 10 children under five were stunted and one of the children under five experienced wasting from this number and two of them experienced wasting. The purpose of this study was to determine the factors that influence stunting in children aged 0-59 months in Jombang. This research is a descriptive analytic study with a sampling technique with simple random sampling. The independent variable in this study was the length of the birth body, while the dependent variable was stunting. This study used an instrument in the form of a questionnaire using the chi-square test. The results showed that 71 toddlers (0-59 months) who had a birth length $(\geq 50 \mathrm{~cm})$ (78.9\%) were not stunted, while 39 under-five children with birth length ( $<50 \mathrm{~cm})$ ( $46.4 \%$ ) who experienced stunting, from the results of the analysis, it was found that there was a relationship between body length at birth and the incidence of stunting in children aged 0-59 months with a value of $p=0.001<0.005$. It can be concluded that children with a birth length of $\geq 50 \mathrm{~cm}$ reduce the incidence of stunting at $<2$ years of age.
\end{abstract}

Keyword : Birth length, Stunting 


\section{PENDAHULUAN}

Gizi merupakan salah satu indikator penentu keberhasilan tumbuh kembang anak yang optimal. Dalam periode dua tahun pertama kehidupan atau periode emas apabila terjadi kekurangan gizi pada selama masa tersebut mengakibatkan munculnya masalah lain, salah satunya yakni pertumbuhan anak menjadi lebih pendek (stunting) dari anak seusianya (Teja, Mohammad. 2019). Gangguan pertumbuhan pada anak akibat dari kurangnya asupan gizi dalam waktu yang lama dapat mempengaruhi terjadinya stunting (anak dengan tinggi badan lebih rendah daripada tinggi badan anak seusianya) (P2PTM, 2018). Banyak faktor yang mempengaruhi terjadinya stunting yang dimulai dari masa kehamilan, balita, usia sekolah, usia kerja, sampai dengan usia lanjut menjadi kecemasan global terhadap generasi di masa depan (TNP2K, 2016). Salah satu faktor yang erat kaitannya dengan terjadinya stunting pada usia 0-24 bulan adalah panjang badan dan berat badan lahir (Svefors, 2019).

Pada tahun 2018, World Health Organization menyebutkan bahwa prevalensi anak balita stunting di Asia masih menunjukkan lebih dari 50\%, dan 39\% anak balita tinggal di Afrika. Di Indonesia pada tahun 2018, satu diantara 10 jumlah anak balita mengalami wasting, dua diantaranya mengalami obesitas dan tiga diantara 10 anak balita mengalami stunting. Berdasarkan Riset Kesehatan Dasar (Riskesdas) 2018 prevalensi stunting di Jawa Timur mencapai 26,91\% masih dalam risiko tinggi. Di Kabupaten Jombang angka stunting mencapai $29,4 \%$. Keadaan tersebut adalah suatu permasalahan yang kompleks dan diperlukan pemecahan masalah tidak dari salah satu faktor penyebab saja.

\section{METODE}

Jenis penelitian ini deskriptif analitik. Sampel penelitian berjumlah 174 responden yang dipilih dengan cara simple random sampling. Variabel bebas adalah panjang badan lahir, sedangkan variabel terikat yaitu stunting. Penelitian ini menggunakan instrumen berupa kuesioner. Pengolahan data dilakukan melalui editing, coding, scoring, tabulating. Uji statistik menggunakan uji chisquare.

\section{HASIL}

Data umum ini menggambarkan tentang karakteristik responden berdasarkan usia dan jenis kelamin, panjang badan lahir, dan stunting pada anak balita.

Tabel 1. Distribusi Frekuensi Responden Berdasarkan Jenis Kelamin

\begin{tabular}{|c|c|c|c|}
\hline \multirow[t]{2}{*}{ No } & \multirow[t]{2}{*}{ Karakteristik } & $\mathbf{n}$ & $\%$ \\
\hline & & 174 & 100 \\
\hline \multirow[t]{3}{*}{1} & \multicolumn{3}{|l|}{ Jenis Kelamin Anak } \\
\hline & Laki-laki & 97 & 55,7 \\
\hline & Perempuan & 77 & 44,3 \\
\hline \multirow[t]{3}{*}{2} & \multicolumn{3}{|l|}{ Usia Anak } \\
\hline & $<24$ bulan & 143 & 82,2 \\
\hline & $\geq 24-59$ bulan & 31 & 17,8 \\
\hline \multirow[t]{3}{*}{3} & \multicolumn{3}{|c|}{ Panjang Badan Lahir } \\
\hline & Pendek $(<50 \mathrm{~cm})$ & 84 & 48,3 \\
\hline & Panjang $(\geq 50 \mathrm{~cm})$ & 90 & 51,7 \\
\hline \multirow[t]{3}{*}{4} & \multicolumn{3}{|l|}{ Stunting } \\
\hline & Tidak Stunting & 116 & 66,6 \\
\hline & Stunting & 58 & 33,3 \\
\hline
\end{tabular}

Berdasarkan tabel 1. Dapat dilihat bahwa sebagian besar hasil dari responden penelitian berjenis kelamin laki-laki 
menunjukkan 97 responden atau sebesar $55,7 \%$. Usia anak dengan usia $<24$ bulan yaitu sebanyak 143 responden penelitian atau sebesar $82,2 \%$. Sebagian besar responden yang mempunyai panjang badan lahir $\geq 50$ $\mathrm{cm}$ sebanyak 90 responden atau sebesar $51,7 \%$. Responden dengan karakteristik tidak stunting sebanyak 116 responden atau sebesar $66,6 \%$.

\section{Data Khusus}

Data khusus ini hubungan antara panjang badan lahir dengan stunting pada balita usia 0-59 bulan di Kabupaten Jombang.

Tabel 2. Analisis Bivariat Panjang Badan Lahir Anak Balita dan Stunting

\begin{tabular}{|l|c|c|c|c|c|}
\hline \multirow{2}{*}{$\begin{array}{l}\text { Kelompok } \\
\text { Variabel }\end{array}$} & \multicolumn{4}{|c|}{ Stunting } & \multirow{2}{*}{ P } \\
\cline { 2 - 5 } & \multicolumn{2}{|c|}{ Tidak Stunting } & \multicolumn{2}{|c|}{ Stunting } & \\
\cline { 2 - 5 } & $\mathrm{n}$ & $\%$ & $\mathrm{n}$ & $\%$ & \\
\hline $\begin{array}{l}\text { Pendek } \\
(<50 \mathrm{~cm})\end{array}$ & 45 & $(53,6)$ & 39 & $(46,4)$ & \multirow{2}{*}{0,001} \\
\hline $\begin{array}{l}\text { Panjang } \\
(\geq 50 \mathrm{~cm})\end{array}$ & 71 & $(78,9)$ & 19 & $(21,1)$ & \\
\hline Total & 116 & $(66,7)$ & 58 & $(33,3)$ & \\
\hline
\end{tabular}

Berdasarkan tabel 2. menunjukkan bahwa anak balita (0-59 bulan) yang memiliki panjang badan lahir $(\geq 50 \mathrm{~cm})$ sebanyak 71 balita $(78,9 \%)$ dan tidak mengalami stunting sedangkan anak balita dengan panjang badan lahir $(<50 \mathrm{~cm})$ sebanyak 39 balita $(46,4 \%)$ mengalami stunting. Hasil dari analisis didapatkan nilai chi-square $\mathrm{p}=0.001<0,005$ menunjukkan adanya hubungan antara panjang badan lahir dengan kejadian stunting hal ini menunjukkan.

\section{PEMBAHASAN}

\section{Hubungan Panjang Badan Lahir Anak Balita Usia 0-59 Bulan Dengan Kejadian Stunting}

Berdasarkan hasil penelitian menunjukkan bahwa kejadian stunting dapat dipengaruhi oleh panjang badan lahir anak, hasil tersebut dapat dilihat pada tabel 2 yaitu analisis bivariat panjang badan lahir anak dan stunting. Anak yang lahir dengan PB $<50 \mathrm{~cm}$ meningkatkan risiko kejadian stunting dibandingkan anak yang lahir dengan $\mathrm{PB} \geq 50$ $\mathrm{cm}$. Sesuai dengan hasil studi yang dilakukan Islam et al (2018) bahwa ibu yang melahirkan anak dengan PB lahir kurang dari $50 \mathrm{~cm}$ meningkatkan risiko terjadinya stunting pada usia 12-24 bulan. Identifikasi panjang badan anak saat lahir dan pada usia satu tahun pertama lahir diperlukan untuk mengintervensi kejadian stunting pada usia selanjutnya (Keino, 2014).

Hasil dari penelitian ini juga sependapat dengan Nshimyiryo (2019) menyatakan hubungan yang erat antara panjang badan lahir dan terjadinya stunting pada anak balita, menurut Partap (2019) faktor tersebut juga dipengaruhi oleh usia ibu saat melahirkan, asupan nutrisi ibu saat hamil, dan penyakit penyerta sehingga akan berdampak tidak hanya pada anak balita namun saat anak pada usia remaja.

Panjang badan lahir anak ditentukan mulai dari awal kehamilan. Dalam masa kehamilan kondisi ibu yang tidak baik seperti malnutrisi, stres, atau memiliki penyakit penyerta dapat menghambat tumbuh kembang janin. Hal tersebut sangat berpengaruh terhadap perkembangan anak balita, yang nantinya apabila bayi yang dilahirkan memiliki panjang badan kurang dari $50 \mathrm{~cm}$ kemungkinan dapat berdampak pada tinggi badan anak di usia dini dan dewasa (Dorelien, 2016).

Jenis kelamin dan usia anak balita tidak berisiko terjadinya stunting. Pada usia kurang dari 2 tahun anak mengalami tumbuh kembang yang sangat cepat pada berat badan, tinggi badan, maupun perkembangan motoriknya sehingga kebutuhan akan zat gizi 
lebih banyak, namun tidak semua balita tercukupi zat gizi tersebut. Masalah yang dihadapi diantaranya balita yang susah makan dibarengi dengan kualitas dan kuantitas ASI yang akan semakin berkurang. Sehingga sampai dengan usia 24 bulan masih sebagai masa adaptasi untuk dapat mengkonsumsi makan yang sesuai dengan usianya (Setyawati, 2018).

\section{KESIMPULAN}

Berdasarkan hasil penelitian dan pembahasan maka didapatkan kesimpulan bahwa adanya hubungan antara panjang badan lahir anak dengan kejadian stunting pada anak balita usia 0-59 bulan.

\section{SARAN}

Bagi tenaga kesehatan meningkatkan evaluasi deteksi dini stunting dan tumbuh kembang anak balita sehingga lebih dini untuk mengetahui dan memberikan intervensi pada anak stunting. Bagi peneliti selanjutnya dapat dijadikan sebagai sumber rujukan untuk penelitian selanjutnya dengan metode dan subjek yang lebih banyak.

\section{DAFTAR PUSTAKA}

Dinas Kesehatan Kabupaten Jombang. 2018. Profil Kesehatan Kabupaten Jombang.

Dorelien Audrey M. 2016. Effect of Birth Month on Child Health and Survival in Sub-Saharan Africa. Public Access, 61(2), pp. 209-230.

Islam MM, Kazi IS, Mustafa M, et al. Risk Factor of Stunting Among Children Living in an Urban Slum of Bangladesh: Finding of A Prospective
Cohort Study. BMC Public Health (2018) 18:197.

Keino S, Guy P, Grace E, Bart B. 2014. Determinan of Stunting and Overweight Among Young Children and Adolescents in Sub-Saharan Africa. Food and Nutrition Bulletin, Vol. 35, No.2.

Kemenkes RI. 2018. Riset Kesehatan Dasar. Kementrian Kesehatan Republik Indonesia.

Nshimyiryo A, Bethany H, Christine M, et al. 2019. Risk Factor For Stunting Among Children Under Five Years: a Cross-Sectional Population-Based Study In Rwanda Using The 2015 Demographic And Health Survey. BMC Public Health 19:175.

Partap U, Elizabeth H.Y, Pascale A, et al. 2019. Characterisation and Correlates of Stunting Among Malaysian Children And Adolescents Aged 6-19 Years. Cambridge University Press

P2PTM Kemenkes RI. 2018. Cegah Stunting. Kementrian Kesehatan Republik Indonesia.

Setyawati, Vilda Ana Veria. 2018. Kajian Stunting Berdasarkan Umur dan Jenis Kelamin Di Kota Semarang. University Research Colloqium 2018.

Svefors P, Oleg S, Eva C, et al. 2019. Relative Importance of Prenatal and Postnatal Determinants Of Stunting:Data Mining Approaches To The MINIM at Cohort, Bangladesh. BMJ Open 2019;9:e025154.

Teja, Mohammad. 2019. Stunting Balita Indonesia Dan Penanggulangannya. INFO Singkat VolXI, No.22//II//Puslit/November/2019. 
Tim Nasional Percepatan Penanggulangan

Kemiskinan. $2017 . \quad 100$

Kabupaten/Kota Propinsi untuk

Intervensi Anak Kerdil (Stunting).

Jakarta : TNP2K. 